\title{
Heterosis, Nature of Gene Action for Yield and Its Components in Tomato (Lycopersicon esculentum Mill.)
}

\author{
Mohamed K. Rakha ${ }^{1}$ and Samah A. Sabry ${ }^{2}$
}

${ }^{1}$ Veget. Res. Dept., Hort. Res. Inst., Agric. Res. Center, Giza, Egypt

${ }^{2}$ Department of Botany, Faculty of Agriculture, Suez Canal University, Ismailia, Egypt

Received: 20 July 2019/ Accepted 08 Oct. 2019 / Publication date: 20 Oct. 2019

\begin{abstract}
The present experiment was performed to classify best combiner parents and cross combinations for developing accomplished hybrids for yield and quality components in tomato, using half diallel analysis for five parents and ten hybrids including; Super Marmande, Peto 86, Super strain B, Edkawy and Red Star. The results indicated that heterosis over high parent gave significant values in most crosses. The combinations of good combiner parental cultivar and best hybrids for each character were estimated according to the best GCA and SCA. Specifically, all the studied traits showed highly significant GCA and SCA values. Therefore, additive and non-additive gene actions were vital in the expression of these traits. Concerning general combining ability, it was found that Red Star'was the best combiner for plant height, number of branches, fruit length, number of fruit locules, and total fruit weight;Peto 86 for leaf area index, fruit shape index and number of fruits per plant, Super strain B for T.S.S. and total fruit yield, and Edkawy' for number of leaves, fruit diameter, number of fruit locules and average fruit weight. The cross $\mathrm{P}_{1} \mathrm{xP}_{2}$ was found to be the best combination for plant height, $\left(\mathrm{P}_{1} \times \mathrm{P}_{3}\right)$ for number of branches/ plant, $\left(\mathrm{P}_{2} \times \mathrm{P}_{5}\right)$ for No. of leaves / plant, $\left(\mathrm{P}_{1} \times \mathrm{P}_{5}\right)$ for total fruit yield and number of fruit per plant, $\left(\mathrm{P}_{2} \times \mathrm{P}_{3}\right)$ for fruit shape index and leaf area index, $\left(\mathrm{P}_{2} \times \mathrm{P}_{4}\right)$ for fruit weigh/ plant, $\left(\mathrm{P}_{2} \times \mathrm{P}_{5}\right)$ for fruit length and number of leaves / plant, $\left(\mathrm{P}_{3} \times \mathrm{P}_{4}\right)$ for fruit diameter, $\left(\mathrm{P}_{3} \times \mathrm{P}_{5}\right)$ for number of fruit locules and $\left(\mathrm{P}_{4} \times \mathrm{P}_{5}\right)$ was the best combination for T.S.S. Effects of additive gene appeared to be more important than non-additive gene effect as reflected on plant height, No. of leave, fruit length, fruit diameter, T.S.S, No. of fruit locules, average fruit weight, No. of fruit / plant, and total fruit weight. However, it was found that nonadditive gene effect appeared to play important roles than additive effect for No. of branches and fruit shape index. In addition, both broad and narrow sense heritability values were high for all studied traits, indicating that all traits were highly heritable.
\end{abstract}

Keywords: Half diallel, Heterosis, combing ability, heritability, tomato, yield and yield related traits

\section{Introduction}

Tomato, formerly classified as Lycopersicon esculentum Wettsd, $(2 \mathrm{n}=2 \mathrm{x}=24)$, named as Solanum lycopersicum Mill. Based on morphological and molecular studies (Peralta et al., 2006). The genus solanum comprises of annual or short lived perennial herbaceous, typical day neutral plant and warm season crop. Tomato is grown in a diversity of climatic conditions and is susceptible to frost and high temperature reasonably.

Tomato crop is one of the most common and extensively grown vegetables next to potato internationally. Its cultivation has become widespread over the subsequent centuries and is now one of the world's major food crops (Frusciante et al., 2000).

Tomato is identified as protective food not only because of its highly nutritional value but also for its high content of antioxidants.

The current mandate of tomato is depending on the industrial and consumer's needs. Consequently, there is an essential need for further development of superior varieties/hybrids of tomato to meet the current necessities. Recently, tomato cultivation under controlled environmental conditions is focused on the huge global horticultural industry economically. For instance, it is considered as poor man's Apple in many countries because of its attractive appearance and nutritional value.

Corresponding Author: Samah A. Sabry, Department of Botany, Faculty of Agriculture, Suez Canal University, Ismailia, Egypt. E-mail: samahyabdelazeem@gmail.com 
In Egypt, tomato production is always limited and prices are high during August. This is due to the unfavorable high temperature prevailing during flowering in the preceding months, which seriously reduces fruit set according to (Metwally et al., 1996). On the other hand, high temperature is one of the most vital constraints on tomato crop and harmfully affects the vegetative and productive process, reduces yield or abnormal development of female reproductive tissues, abnormal pollen production, hormonal imbalances, low level of carbohydes and deficiency of pollination which causes reduction in the yield and fruit quality (Peet et al.,1997).

Hybrid vigour in tomato was first determined by Hedrick and Booth (1907). Exploitation of heterosis in vegetable crops was done in various aspects with great improvement. The commercial possibilities of F1 hybrid production in tomato have been reported by Wellington (1912). Breeding of F1 hybrid is prominent among the approaches used in the crop enhancement of vegetable crops. According to Hallauer (1999) "The exact genetic basis of heterosis may never be known and understood because of allelic interactions: interactions of alleles at a locus, interactions of alleles at different loci, interactions of the nucleus and cytoplasm, and interactions of the genotype and environment but heterosis will continue to have a main role in the future plant improvement even though our knowledge on its genetic basis is limited." Tomato is a self-pollinated inbred crop and the high level of heterosis might not be manifested in tomato F1 hybrids. However, heterosis in tomato was monitored in several crosses. Hybrids introduce opportunities for improving earliness, productivity, uniformity and quality of yield owing to the rapid of dominant genes for enhancing the resistance to pests and diseases Riggs (1988). Therefore, an effective character improvement to concentrate breeding efforts are desired.

Hybrid breeding achieves heterosis and helps private breeders in controlling their products independently without legal patents or plant breeder's rights.

Tomato being a self- pollinated crop has enormous potential for heterosis breeding. That is why, many commercial hybrids have been developed.

Hybrid vigor and parents could exploit and select based on combining ability through breeding approaches in crop improvement. The combining ability is principally valuable in assembly with testing procedures in which it is anticipated to investigate and compare the performance of a line in hybrid combination. GCA effects caused by the additive type of gene action and SCA effects are due to non-additive (dominant or epistatic) gene action. Half diallel cross analysis was proposed by (Griffing, 1956). It is the quickest and most appropriate approach for obtaining worthwhile information on different cross combinations by assessing the genetic makeup of parental lines. Through this method, the GCA and SCA effects with very effective genetic information for deciding the next phase of breeding programme are obtained. Valuable information on heritability and heterosis can be easily obtained. It also helps in the selection of suitable parents for hybridization.

The present experiment was carried out to identify best combiner parents and best cross combinations for developing promising hybrids for yield and quality components that can be produced locally. This would make it possible to produce hybrids at cheaper costs.

\section{Materials and Methods}

The present investigation was carried out during (April - October) of 2017 and 2018, at Meat Salseil City, Dakahlia Governorate, Egypt. The experimental materials were obtained from the Vegetable Research Institute, Agricultural Research Center (A.R.C.) Ministry of Agriculture, Egypt. Which comprises 5 varieties of tomato. All varieties belong to the species Lycopersican esculentum Mill. These parental varieties were 'Super Marmande' $\left(\mathrm{P}_{1}\right)$, Peto86 $\left(\mathrm{P}_{2}\right)$,' Super strain B' $\left(\mathrm{P}_{3}\right)$, 'Edkawy' $\left(\mathrm{P}_{4}\right)$ and Red Star $\left(\mathrm{P}_{5}\right)$.

Seeds of parental varieties were sown in a nursery on $15^{\text {th }}$ of April, 2017, and transplanted to main filed on 20 May, 2017, 40 cm apart. Each plot was two rows of $6 \mathrm{~m}$ long and $1.25 \mathrm{~m}$ wide, thus making an area of $15 \mathrm{~m}^{2}$. Crosses were made manually by using the standard procedure of hand emasculation and pollination in the growing season of 2017 to obtain 10 F1 Hybrids through half diallel crosses mating design. These parental varieties versed with recommended package and practices were applied to raise good crops and respect to the time of complete maturity and fruit characteristics. The genetic material which included five parental varieties and 10 F1 Hybrids were evaluated in the growing season of 2018 . 
The experimental design used was the randomized complete blocks design (RCBD) with three replications.

Data of ten randomly selected plants of each variety and its crosses in each replication were recorded for plant height $(\mathrm{cm})$, number of branches per plant, , number of leaves per plant, , leaf area index $\left(\mathrm{cm}^{2}\right)$, length of fruit $(\mathrm{cm})$, fruit diameter $(\mathrm{cm})$, fruit shape index $(\mathrm{L} / \mathrm{D})$, number of fruit locules, average fruit weight $(\mathrm{g})$, number of fruit per plant, total fruit weight Per plant $(\mathrm{kg})$ and quality parameters, viz. total soluble solid (TSS) with help of hand refractometer in ${ }^{\circ}$ brix. The reading was taken from freshly harvested fruit, and averaged replication with mean data was used for statistical analysis.

Analysis of variance of complete randomized block design was conducted, and L.S.D. test was used for the comparison among genotypes (the difference among means for all traits for significant according to Cochran and cox (1957), relative increase (\%) according to Andre (1972).Provide the information about general and specific combining ability and their effects were determined as per the procedure given by Griffing (1956).

The previous used to estimate heterosis over mid and better parent according to formulae adapted by Bhatt (1971) as follow:-

$$
\begin{gathered}
\text { Heterosis over mid parent }=\frac{F_{1}-M . P}{M . P} \times 100 \\
\text { Heterosis over better parent }=\frac{F 1-B . P}{B . P} \times 100
\end{gathered}
$$

Heritability values in broad Sense $\left(h^{2} b \%\right)$ and narrow sense $\left(h^{2} n \%\right)$ were calculated according to Mather and Jinks, (1971).

\section{Results and Discussion}

Mean Performance of Parents and F1 Hybrids

The mean performance of parents and crosses for growth, yield and fruit quality attributing traits is presented in (Table1).

\begin{tabular}{|c|c|c|c|c|c|c|c|c|c|c|c|c|}
\hline \multirow[b]{2}{*}{ Crosses } & \multirow[b]{2}{*}{$\begin{array}{c}\text { Plant } \\
\text { Height } \\
\text { (cm) }\end{array}$} & \multicolumn{5}{|c|}{ Morphological characters } & \multicolumn{6}{|c|}{ Yield and its component } \\
\hline & & $\begin{array}{c}\text { No. } \\
\text { of } \\
\text { branches } \\
\text { /plant }\end{array}$ & $\begin{array}{c}\text { No. } \\
\text { of } \\
\text { Leaves } \\
\text { /plant }\end{array}$ & $\begin{array}{c}\text { Leaf } \\
\text { Area } \\
\text { index }\end{array}$ & $\begin{array}{c}\text { Fruit } \\
\text { Length }\end{array}$ & $\begin{array}{c}\text { Fruit } \\
\text { diameter }\end{array}$ & $\begin{array}{c}\text { Fruit } \\
\text { Shape } \\
\text { index }\end{array}$ & T.S.S. & $\begin{array}{c}\text { No. of } \\
\text { Fruit } \\
\text { locules }\end{array}$ & $\begin{array}{c}\text { Aver. } \\
\text { Fruit } \\
\text { weight(g) }\end{array}$ & $\begin{array}{c}\text { No. } \\
\text { of } \\
\text { fruits/ } \\
\text { plant }\end{array}$ & $\begin{array}{c}\text { Total } \\
\text { Fruit } \\
\text { weight } \\
\text { (kg) }\end{array}$ \\
\hline P1 & 98.33 & 6.67 & 60.33 & 268.94 & 4.31 & 4.75 & 0.91 & 5.39 & 3.86 & 89.33 & 23.33 & 1.95 \\
\hline $\mathbf{P 2}$ & 60.79 & 8.33 & 42.67 & 284.22 & 4.89 & 4.36 & 1.12 & 5.58 & 2.88 & 47.00 & 46.00 & 2.04 \\
\hline P5 & 81.10 & 9.67 & 78.67 & 263.16 & 6.95 & 8.06 & 0.86 & 5.92 & 4.34 & 80.33 & 34.00 & 2.12 \\
\hline $\mathbf{P 1}$ *P2 & 101.42 & 8.00 & 54.67 & 275.15 & 3.76 & 4.3 & 0.87 & 5.35 & 3.77 & 75.00 & 35.67 & 1.98 \\
\hline $\mathbf{P 1} * \mathbf{P 3}$ & 77.98 & 10.33 & 43.33 & 245.25 & 4.41 & 4.8 & 0.92 & 6.72 & 2.91 & 104.33 & 27.67 & 2.12 \\
\hline$P 1 * P 4$ & 81.31 & 7.67 & 83.33 & 257.41 & 5.91 & 7.85 & 0.75 & 4.90 & 4.89 & 98.00 & 19.67 & 1.90 \\
\hline$P 1 * P 5$ & 103.86 & 9.00 & 75.67 & 253.08 & 5.86 & 7.04 & 0.83 & 5.66 & 3.93 & 87.33 & 32.67 & 2.27 \\
\hline $\mathbf{P 2} * \mathbf{P 3}$ & 66.56 & 6.33 & 32.67 & 280.49 & 4.95 & 3.86 & 1.28 & 6.09 & 2.48 & 86.00 & 38.00 & 2.27 \\
\hline P4*P5 & 68.10 & 7.67 & 77.33 & 251.66 & 6.8 & 7.7 & 0.88 & 5.07 & 4.71 & 94.67 & 20.33 & 1.95 \\
\hline $\begin{array}{c}\text { L.S.D } \\
5 \%\end{array}$ & 3.33 & 1.87 & 3.84 & 5.68 & 0.16 & 0.24 & 0.06 & 0.17 & 0.11 & 4.25 & 3.02 & 0.07 \\
\hline $\begin{array}{l}\text { L.S.D } \\
1 \%\end{array}$ & 4.50 & 2.53 & 5.19 & 7.66 & 0.21 & 0.32 & 0.07 & 0.23 & 0.14 & 5.74 & 4.08 & 0.10 \\
\hline
\end{tabular}

Table 1: Mean performance for all studied traits in 2018 season

Highly significant differences were observed among genotypes (parents and crosses) for plant height (Table 1). Among the parents, plant height ranged from $98.33 \mathrm{~cm}$ for $\mathrm{P}_{1}$ to $60.79 \mathrm{~cm}$ for $\mathrm{P}_{2}$. Hybrids showed maximum mean value of $103.86 \mathrm{~cm}$ for cross $\mathrm{P}_{1} \times \mathrm{P}_{5}$ with increased value of $5.62 \%$ and 28,06 
$\%$ as compared to $\mathrm{P}_{1}$ and $\mathrm{P}_{5}$, respectively, followed by $\mathrm{P}_{1} \mathrm{x} \mathrm{P}_{2}$ with mean value of $101.42 \mathrm{~cm}$ with increased value of $3.14 \%$ and $66.8 \%$ as compared to $\mathrm{P}_{1}$ and $\mathrm{P}_{2}$, respectively. While minimum mean value of $58.38 \mathrm{~cm}$ was recorded for cross $\mathrm{P}_{2} \mathrm{XP}_{4}$

Among the parents, the number of branches ranged from 9.67 for $\mathrm{P}_{5}$ to 6.00 for $\mathrm{P}_{4}$. The hybrid $\mathrm{P}_{1} \mathrm{xP}_{3}$ had the highest mean value of 10.33 with increase value of $54.87 \%$ and $40.93 \%$ as compared to $\mathrm{P}_{1}$ and $\mathrm{P}_{3}$, respectively. Followed by $\mathrm{P}_{1} \times \mathrm{P}_{4}$ with mean value of 7.67 with increased value of $14.99 \%$ and 27.83 $\%$ as compared to $\mathrm{P}_{1}$ and $\mathrm{P}_{4}$, respectively. The hybrid $\mathrm{P}_{3} \mathrm{xP}_{5}$ had the minimum mean value of 5.67 for number of branches.

Mean value for number of leaves in parents ranged from 82.33 for $\mathrm{P}_{4}$ to 31.00 for $\mathrm{P}_{3}$. Hybrids showed maximum mean value of 83.33 for cross $\mathrm{P}_{1} \mathrm{XP}_{4}$ with increased value of $38.12 \%$ and $1.21 \%$ as compared to $\mathrm{P}_{1}$ and $\mathrm{P}_{4}$ respectively. This was the only hybrid with increased value over the parents. While minimum mean value of $32.67 \mathrm{~cm}$ was for cross $\mathrm{P}_{2} \mathrm{XP}_{3}$.

The leaf area index ranged from 284.22 for $\mathrm{P}_{2}$ to 220.70 for $\mathrm{P}_{3}$. The hybrid $\mathrm{P}_{2} \mathrm{xP}_{3}$ had the highest mean value of 280.49 , followed by $\mathrm{P}_{1} \mathrm{xP}_{2}$ with main value of 275.15 , while the hybrid $\mathrm{P}_{3} \times \mathrm{P}_{4}$ had the minimum mean value of 225.3 for leaf area index. No hybrid scored any increase in leaf area index. Among the parents, fruit length ranged from $6.95 \mathrm{~cm}$ for P5 to $4.31 \mathrm{~cm}$ for P1.hybrids showed maximum mean value of $6.80 \mathrm{~cm}$ for cross $\mathrm{P}_{4} \times \mathrm{X}_{5}$, followed by $\mathrm{P}_{2} \mathrm{XP}_{5}$ with main value of $6.72 \mathrm{~cm}$ while minimum mean value of $3.76 \mathrm{~cm}$ for cross $\mathrm{P}_{1} \mathrm{XP}_{2}$. No hybrid scored any increase in fruit length.

Mean value for fruit diameter in parents ranged from 9.05 for $\mathrm{P}_{4}$ to $4.36 \mathrm{~cm}$ for $\mathrm{P}_{2}$. Hybrids showed maximum mean value of $7.94 \mathrm{~cm}$ for cross $\mathrm{P}_{3} \times \mathrm{P}_{4}$, followed by $\mathrm{P}_{1} \mathrm{XP}_{4}$ with mean value of $7.85 \mathrm{~cm}$, while minimum mean value of $3.86 \mathrm{~cm}$ for cross $\mathrm{P}_{2} \mathrm{xP}_{3}$.Cross $\mathrm{P}_{1} \mathrm{xP}_{3}$ with mean value of $4.80 \mathrm{~cm}$ with the same increased value of $1.05 \%$ as compared to $\mathrm{P}_{1}$ and $\mathrm{P}_{3}$. Cross $\mathrm{P}_{1} \times \mathrm{P}_{3}$ was the only one with increased value over the parents.

For fruit shape index in parents, ranged from 1.12 for $\mathrm{P}_{2}$ to 0.70 for $\mathrm{P}_{4}$. Hybrids showed maximum mean value of 1.28 for cross $\mathrm{P}_{2} \times \mathrm{P}_{3}$ with increased value of $14.29 \%$ and $15.32 \%$ as compared to $\mathrm{P}_{2}$ and $\mathrm{P}_{3}$, respectively, followed by $\mathrm{P}_{4} \times \mathrm{P}_{5}$ with mean value of 0.88 with increased value of $25.71 \%$ and $2.33 \%$ as compared to $\mathrm{P}_{4}$ and $\mathrm{P}_{5}$, respectively. Minimum mean value of $0.61 \mathrm{~cm}$ for cross $\mathrm{P}_{3} \times \mathrm{P}_{4}$.

Total Soluble Solids ( ${ }^{\circ}$ Brix) exhibited variations among treatments which ranged from 9.44 for $\mathrm{P}_{3}$ to 4.50 for $\mathrm{P}_{4}$ among the parents. Hybrids showed maximum mean value of 6.72 for cross $\mathrm{P}_{1} \mathrm{XP}_{3}$, followed by $\mathrm{P}_{3} \mathrm{XP}_{5}$ with main value of 6.59 while minimum mean value of 4.58 for cross $\mathrm{P}_{3} \mathrm{xP}_{4}$. None of the hybrids scored any increase in total soluble solids over Parents.

Mean value for fruit locules number in parents ranged from 6.05 for $\mathrm{P}_{4}$ to 2.85 for $\mathrm{p}_{3}$. Hybrids showed maximum mean value of 5.10 for cross $\mathrm{P}_{3} \mathrm{xP}_{5}$, with increased value of $78.95 \%$ and $17.51 \%$ as compared to $\mathrm{P} 3$ and $\mathrm{P} 5$ respectively. This was the only hybrid with increased value over the parents. Minimum mean value of 2.48 was recorded for cross $\mathrm{P}_{2} \times \mathrm{P}_{3}$.

For average fruit weight in parents, it ranged from $102.32 \mathrm{~g}$ for $\mathrm{P} 4$ to $47.00 \mathrm{~g}$ for $\mathrm{P}_{2}$. Hybrids showed maximum mean value of $104.33 \mathrm{~g}$ for cross $\mathrm{P}_{1} \mathrm{XP}_{3}$ with increased value of $16.79 \%$ and $15.92 \%$ as compared to $\mathrm{P}_{1}$ and $\mathrm{P}_{3}$, respectively, while minimum mean value of $70.67 \mathrm{~g}$ was recorded for cross $\mathrm{P}_{2} \mathrm{XP}_{5}$.

Mean value for number of fruits / plant in parents ranged from 46.00 for $\mathrm{P}_{2}$ to 20.67 for $\mathrm{P}_{4}$. Hybrids showed maximum mean value of 39.67 for cross $\mathrm{P}_{2} \mathrm{xP}_{5}$. While minimum mean value of 19.67 was for cross $\mathrm{P}_{1} \times \mathrm{P}_{4}$.

For total fruit weight in parents the mean value ranged from 2.37 for P3 to 1.95 for $\mathrm{P}_{1}$. Hybrids showed maximum mean value of $2.48 \mathrm{~cm}$ for cross $\mathrm{P}_{3} \mathrm{xP}_{5}$ with increased value of $4.64 \%$ and $16.98 \%$ as compared to $\mathrm{P} 3$ and $\mathrm{P}_{5}$, respectively, followed by $\mathrm{P}_{1} \times \mathrm{P}_{5}$ with main value of 2.27 with increased value of $16.41 \%$ and $7.08 \%$ as compared to $\mathrm{P}_{1}$ and $\mathrm{P}_{5}$, respectively, while minimum mean value of 1.90 was for cross $\mathrm{P}_{1} \mathrm{xP}_{4}$

\section{Heterosis}

Heterosis was estimated as per cent increase or decrease of F1 values over mid parent (MP) and better parent (BP) as well as inbreeding depression. The extent of heterosis and inbreeding depression for different characters is presented in Tables (2 and 3$)$.

Relative mid-parent heterosis (Table 2 ) for plant height $(\mathrm{cm})$ ranged from -5.39 per cent $\left(\mathrm{P}_{3} \mathrm{xP}_{5}\right)$ to 27.48 percent $\left(\mathrm{P}_{1} \times \mathrm{P}_{2}\right)$ and better parent heterosis from $-6.39 \%\left(\mathrm{P}_{2} \times \mathrm{P}_{3}\right)$ to $5.62 \%\left(\mathrm{P}_{1} \times \mathrm{P}_{5}\right)$. Highly significant positive heterosis was observed for the two hybrids $\mathrm{P}_{1} \times \mathrm{P}_{2}(27.48 \%)$ and $\mathrm{P}_{1} \times \mathrm{P}_{5}(15.77 \%)$ 
over mid - parent. But only one hybrid $\left(\mathrm{P}_{1} \mathrm{XP}_{5}\right) 5.62 \%$ played significant positive heterosis over high parent.

These findings conform the previous reports of (Patil, 1997; Singh et al., 2006; Rani and Veeraragavathatham, 2008; Sharma and Thakur, 2008; Singh et al., 2008; Kumari and Sharma, 2011). Singh and Asati (2011) also noticed heterosis in favorable direction. Heterosis range (-29.13 to 33.26\%), was reported by (Kumari and Sharma, 2011;Shankar et al., 2013; Solieman et al., 2013; Madhavi et al. ,2013; Syarifah et al., 2016; Savita and singh, 2017; Vramana et al., 2018 and Pramod et al.,2019).

Heterosis for number of branches/ plant was found in a range of $-33.29 \%\left(\mathrm{p}_{3} \times \mathrm{P}_{5}\right)$ to $47.57 \%\left(\mathrm{P}_{1} \mathrm{x}\right.$ $\left.\mathrm{P}_{3}\right)$ over mid parent and $-20.68 \%\left(\mathrm{P}_{4} \times \mathrm{P}_{5}\right)$ to $40.93 \%\left(\mathrm{P}_{1} \times \mathrm{P}_{3}\right)$ over better parent.

The highly significant positive heterosis was found for P1 x P3 (47.57\%) over mid parent and for hybrid $\mathrm{P}_{1} \times \mathrm{P}_{3}(40.93 \%)$ over better parent. Number of branches is also a vital character which indirectly associated with the total yield. Considerable genetic variation was revealed for number of branches per plant. Similar heterosis range of -42.15 to 39.46 per cent was stated byKumar et al. (2009). Results of the experiment with respect to number of branches per plant were similar to the findings of (Dundi and Madalogeri, 1991; Asati et al., 2007; Singh et al., 2008; Singh and Asati, 2011; Shankar et al.,2013; Solieman et al.,2013; Madhavi et al., 2013; Syarifahet al.,2016; Savita and singh,2017; V Ramana et al.,2018 and Pramod et al., 2019).

Heterosis for number of leaves/ plant varied from -11.31 to $22.52 \%$ over mid parent, and from 5.52to $-28.18 \%$ over better parent. Maximum value for highly significant positive heterosis was found in hybrid $\mathrm{P}_{2} \times \mathrm{P}_{5}(22.52 \%)$, followed by $\mathrm{P}_{3} \times \mathrm{P}_{5}(18.54 \%), \mathrm{P}_{1} \times \mathrm{P}_{4}(16.82 \%), \mathrm{P}_{3} \times \mathrm{P}_{4}(11.76 \%)$ and $\mathrm{P}_{1} \times \mathrm{P}_{5}(8.88 \%)$. One cross $\mathrm{P}_{2} \times \mathrm{P}_{4}$ revealed significant positive heterosis $6.13 \%$ over mid parent. No significant useful heterosis was found over better parent.

Regarding heterosis for Leaf area index, maximum value of $11.10 \%$ was recorded for cross $\mathrm{P}_{2} \times \mathrm{P}_{3}$ followed by $\mathrm{P}_{3} \times \mathrm{P}_{5}$ with heterotic value $3.41 \%$ of highly significant useful effect over mid parent. None of the hybrid was recorded significant or highly significant useful effects over high parent.

Heterosis for fruit length $(\mathrm{cm})$ ranged from $-8.03 \%$ to $13.51 \%$ over mid parent. Highly significant positive heterosis was recorded for four hybrids $\left(\mathrm{P}_{2} \times \mathrm{P}_{5}\right) \quad(13.51 \%), \mathrm{P}_{1} \times \mathrm{P}_{4}(11.40 \%), \mathrm{P}_{2} \times \mathrm{P}_{4}$ $(4.74 \%)$ and $\mathrm{P}_{1} \times \mathrm{P}_{5}(4.09 \%)$ over mid parent. Only one hybrid $\left(\mathrm{P}_{4} \mathrm{XP}_{5}\right) 2.64 \%$ played significant positive heterosis over mid parent. None of the hybrids recorded significant or highly significant useful effects over high parent for fruit length. Maximum negative heterosis over mid parent and better parent was recorded in $\mathrm{P}_{1} \times \mathrm{P}_{2}$ and $\mathrm{P}_{3} \times \mathrm{P}_{5}$ which was -18.26 and -25.90 respectively. Fruit length is a crucial character prompting fruit quality. Fruits with more length and diameter are desirable for both consumption and processing. Significant heterosis for fruit length and width in tomato were reported previously (Sharma et al., 2001; Geleta and Labuschagne, 2004; Mahendrakar, 2004; Kumar et al., 2006).Regarding heterosis for fruit diameter. maximum value of $17.56 \%$ was recorded for cross $\mathrm{P}_{3} \times \mathrm{P}_{5}$ followed by $\mathrm{P}_{3} \times \mathrm{P}_{4}$ with heterotic value $15.07 \%, \mathrm{P}_{1} \times \mathrm{P}_{4}(13.77 \%), \mathrm{P}_{2} \times$ $P_{5}$ ( 9.98) and $P_{1} \times P_{5}$ with heterotic value 9.91 of highly significant useful effect over mid parent. None of the hybrid was found with significant or highly significant useful effects over high parent. The results of heterosis for fruit diameter are in close agreement with the findings of (Sharma et al., 2001; Singh et al., 2006; Asatiet al., 2007; and Saleem et al., 2009).

For fruit shape index, heterosis varied from -6.21 to $14.80 \%$ over mid parent, and from -8.79 to 14.29 $\%$ over better parent. Maximum value for highly significant positive heterosis was found in hybrid $\mathrm{P}_{2}$ x $\mathrm{P}_{3}(14.80 \%)$ followed by $\mathrm{P}_{4} \times \mathrm{P}_{5}(12.82 \%)$. One cross $\mathrm{P}_{2} \times \mathrm{P}_{4}$ revealed significant positive heterosis $5.49 \%$ over mid parent. Maximum value for highly significant positive heterosis was found in hybrid $\mathrm{P}_{2} \times \mathrm{P}_{3}(14.29 \%)$ followed by $\mathrm{P}_{4} \times$ P5 (2.33\%) over better parent. No significant useful heterosis was found over better parent.

Regarding the heterosis of total soluble solids, none of the hybrids was found with significant or highly significant useful effects over mid or high parent. Highly significant negative heterosis in most crosses were observed in both mid and high parent. Tomato ranks first among processed vegetables in the world. High T.S.S. is one of the major factors considered for manufacture of processed products. One percent increase in T.S.S. content of fruits results in 20 per cent increase in recovery of processed product (Berry and Uddin, 1991). These results are in dis agreement with the findings of (Hassan et al., 2000; Kurian and Peter, 2001;Parattaet al., 2003;Khalf-Allah et al. ,2005; Singh et al. ,2005; Singh et al. ,2006; Kumar et al. ,2006; Singh et al. ,2007; Singh, et al. ,2008;Shankarappaet al. ,2008; 
Table 2: Estimation of heterosis \% as percentage of mid parents for all studied traits in 2018 season

\begin{tabular}{|c|c|c|c|c|c|c|c|c|c|c|c|c|}
\hline Crosses & $\begin{array}{c}\text { Plant } \\
\text { Height } \\
\text { (cm) }\end{array}$ & $\begin{array}{c}\text { No. of } \\
\text { Branches } \\
\text { /plant } \\
\end{array}$ & $\begin{array}{c}\text { No. of } \\
\text { Leaves } \\
\text { /plant }\end{array}$ & $\begin{array}{l}\text { Leaf } \\
\text { Area } \\
\text { index } \\
\end{array}$ & $\begin{array}{l}\text { Fruit } \\
\text { length }\end{array}$ & $\begin{array}{c}\text { Fruit } \\
\text { diameter }\end{array}$ & $\begin{array}{l}\text { Fruit } \\
\text { shape } \\
\text { index }\end{array}$ & T.S.S. & $\begin{array}{c}\begin{array}{c}\text { No. of } \\
\text { Fruit } \\
\text { locules }\end{array} \\
\end{array}$ & $\begin{array}{c}\text { Aver. } \\
\text { Fruit it } \\
\text { weight(g) }\end{array}$ & $\begin{array}{l}\text { No. of } \\
\text { Fruits } \\
\text { / plant } \\
\end{array}$ & $\begin{array}{c}\text { Total Fruit } \\
\text { fruit weight } \\
(\mathrm{kg})\end{array}$ \\
\hline P1*P2 & $27.48 * *$ & 6.67 & 6.16 & -0.52 & $-18.26 * *$ & $-5.6^{*}$ & $-14.29 * *$ & -2.46 & $11.87 * *$ & $10.03 * *$ & $2.90 *$ & -0.75 \\
\hline P1 *P3 & $-7.95 * *$ & $47.57 * *$ & -5.11 & 0.18 & $-8.03 * *$ & 1.05 & $-8.91 * *$ & $-12.33 * *$ & $-13.26^{* *}$ & $16.36^{* *}$ & $8.51 * *$ & -1.85 \\
\hline P1*P4 & -1.45 & 21.07 & $16.82 * *$ & $-1.93 *$ & $11.40 * *$ & $13.77 * *$ & $-6.83^{*}$ & -0.91 & -1.31 & $2.26^{*}$ & -10.59 & $-3.06 *$ \\
\hline P1*P5 & $15.77 * *$ & 10.16 & $8.88 * *$ & $-4.88 * *$ & $4.09 * *$ & $9.91 * *$ & $-6.21^{*}$ & 0.00 & $-4.15 * *$ & 2.95 & $13.97 * *$ & $11.55^{* *}$ \\
\hline$P 2 * P 3$ & 0.93 & -19.16 & $-11.31^{*}$ & $11.1 * *$ & -2.65 & $-15.26^{* *}$ & $14.80 * *$ & $-12.52 * *$ & $-13.49 * *$ & $25.55^{* *}$ & 3.16 & $2.95^{*}$ \\
\hline$P 2 * P 4$ & $-8.41 * *$ & 16.26 & $6.13 *$ & $-3.85 * *$ & $4.74 * *$ & $-9.32 * *$ & $5.94 *$ & $-8.93 * *$ & $13.99 * *$ & $24.56^{* *}$ & $8.98 *$ & $-3.74 *$ \\
\hline P2 $*$ P5 & 1.71 & -3.67 & $22.52 * *$ & -1.33 & $13.51 * *$ & $9.98 * *$ & -1.01 & $-8.87 * *$ & $15.24 * *$ & $11.00 * *$ & -0.83 & $-3.37 *$ \\
\hline P3*P5 & $-5.39 * *$ & $-33.29 * *$ & $18.54 * *$ & $3.41 * *$ & $-15.78 * *$ & $17.56^{* *}$ & $-30.96 * *$ & $-16.9 * *$ & $41.86^{* *}$ & -0.98 & 2.71 & $10.47 * *$ \\
\hline P4*P5 & $-7.84 * *$ & -2.11 & -3.94 & $-3.05 * *$ & $2.64 *$ & $-9.99 * *$ & $12.82 * *$ & -2.7 & $-9.34 * *$ & 3.66 & $-25.63 * *$ & $-4.65 * *$ \\
\hline L.S.D \%5 & 2.88 & 1.63 & 3.33 & 4.92 & 0.14 & 0.20 & 0.04 & 0.14 & 0.09 & 3.68 & 2.62 & 0.06 \\
\hline L.S.D \%1 & 3.89 & 2.19 & 4.49 & 6.64 & 0.19 & 0.28 & 0.06 & 0.2 & 0.12 & 4.97 & 3.53 & 0.09 \\
\hline
\end{tabular}

Table 3: Estimation of heterosis \% as percentage of high parents for all studied traits in 2018 season

\begin{tabular}{|c|c|c|c|c|c|c|c|c|c|c|c|c|}
\hline Crosses & $\begin{array}{c}\text { Plant } \\
\text { Height } \\
\text { (cm) }\end{array}$ & $\begin{array}{c}\text { No. of } \\
\text { branches } \\
\text { /plant }\end{array}$ & $\begin{array}{c}\text { No. of } \\
\text { Leaves } \\
\text { /plant }\end{array}$ & $\begin{array}{l}\text { Leaf } \\
\text { Area } \\
\text { index }\end{array}$ & $\begin{array}{l}\text { Fruit } \\
\text { length }\end{array}$ & $\begin{array}{c}\text { Fruit } \\
\text { diameter }\end{array}$ & $\begin{array}{l}\text { Fruit } \\
\text { shape } \\
\text { index }\end{array}$ & T.S.S. & $\begin{array}{c}\text { No. of } \\
\text { Fruit } \\
\text { locules }\end{array}$ & $\begin{array}{c}\text { Aver. } \\
\text { Fruit } \\
\text { Weight } \\
\text { (g) }\end{array}$ & $\begin{array}{l}\text { No. of } \\
\text { fruits/ } \\
\text { plant }\end{array}$ & $\begin{array}{c}\text { Total } \\
\text { fruit } \\
\text { Weight } \\
\text { (kg) }\end{array}$ \\
\hline P1*P2 & 3.14 & -3.96 & $-9.83 * *$ & $-3.19 * *$ & $-23.11 * *$ & $-9.47 * *$ & $-22.32 * *$ & $-4.12 * *$ & -2.33 & $-16.04 * *$ & $-22.46^{* *}$ & -2.94 \\
\hline P1 *P3 & $-20.70 * *$ & $40.93 * *$ & $-28.18 * *$ & $-8.81 * *$ & $-16.48 * *$ & 1.05 & $-17.12 * *$ & $-23.39 * *$ & $-24.61 * *$ & $15.92 * *$ & 0.00 & $-10.55^{* *}$ \\
\hline P1 *P4 & $-17.31 * *$ & 14.99 & 1.21 & $-4.29 * *$ & $-6.19 * *$ & $-13.26^{* *}$ & $-17.58^{* *}$ & $-9.09 * *$ & $-19.17 * *$ & $-4.23 *$ & $-15.69 *$ & $-3.55^{*}$ \\
\hline P1 *P5 & $5.62 * *$ & -6.93 & -3.81 & $-5.90 * *$ & $-15.68 * *$ & $-12.66^{* *}$ & $-8.79 * *$ & $-4.39 * *$ & $-9.45^{* *}$ & -2.24 & -3.91 & $7.08^{* *}$ \\
\hline P2 $*$ P3 & $-6.39 * *$ & $-24.01^{*}$ & $-23.44 * *$ & -1.31 & $-6.25^{* *}$ & $-18.74 * *$ & $14.29 * *$ & $-38.73 * *$ & $-13.89 * *$ & -4.44 & $-17.39 * *$ & $-4.22 * *$ \\
\hline P2*P4 & $-12.46^{* *}$ & 0.00 & $-19.43 * *$ & $-8.62 * *$ & $-6.98 * *$ & $-32.82 * *$ & $-14.29 * *$ & $-17.74 * *$ & $-15.87 * *$ & $-9.12 * *$ & $-21.02 * *$ & $-5.39 * *$ \\
\hline P2 $*$ P5 & $-11.02 * *$ & -10.34 & $-5.52 *$ & $-4.99 * *$ & $-3.31 * *$ & $-15.26^{* *}$ & $-12.50 * *$ & $-11.49 * *$ & $-4.15^{* *}$ & $-12.03 * *$ & $-13.76^{* *}$ & $-5.19 * *$ \\
\hline P3*P4 & $-9.92 * *$ & -18.14 & $-23.08 * *$ & $-11.99 * *$ & $-23.02 * *$ & $-12.27 * *$ & $-45.05^{* *}$ & $-53.92 * *$ & $-33.70 * *$ & -1.30 & -8.46 & $-7.59 * *$ \\
\hline P3*P5 & $-11.22 * *$ & -41.37 & $-17.38 * *$ & $-4.94 * *$ & $-25.90 * *$ & $-6.58 * *$ & $-38.74 * *$ & $-33.70 * *$ & $17.51^{* *}$ & $-6.3 *$ & -6.85 & $4.64 * *$ \\
\hline P4*P5 & $-16.03 * *$ & $-20.68 *$ & $-6.07^{*}$ & $-4.37 * *$ & -2.16 & $-14.92 * *$ & $2.33 * *$ & $-14.36^{* *}$ & $-22.15 * *$ & $-7.49^{* *}$ & $-40.21 * *$ & $-8.02 * *$ \\
\hline L.S.D \%5 & 3.33 & 1.87 & 3.84 & 5.68 & 0.16 & 0.24 & 0.05 & 0.17 & 0.10 & 4.25 & 3.02 & 0.07 \\
\hline L.S.D \% 1 & 4.50 & 2.53 & 5.19 & 7.66 & 0.21 & 0.32 & 0.07 & 0.23 & 0.14 & 5.74 & 4.08 & 0.10 \\
\hline
\end{tabular}


Kumar et al., 2009; and Kumari and Sharma ,2011) That may be due to diversity in experimental materials and variable environmental conditions For number of fruit locules, heterosis ranged from 4.15 to $41.86 \%$ over mid parent and from -4.15 to $17.51 \%$ over better parent. Maximum value for highly significant positive heterosis was found in hybrid $\mathrm{P}_{3} \times \mathrm{P}_{5}(41.86 \%)$ followed by $\mathrm{P}_{2} \times \mathrm{P}_{5}(15.24$ $\%), \mathrm{P}_{2} \times \mathrm{P}_{4}(13.99 \%)$ and $\mathrm{P}_{1} \times \mathrm{P}_{2}(11.87 \%)$. Only one hybrid has useful highly significant positive heterosis $\mathrm{P}_{3} \times \mathrm{P}_{5}(17.51 \%)$ over better parent.

Number of locules decides the fruit shape and amount of juice and therefore preferred by processing industries. Less number of locules is favored by farmers and consumers because these fruits will be firm. Most significant decrease in locule number was noticed in cross combination. Similar findings for number of locules were reported by (Kurian et al.,2001; Singh et al. ,2006; Singh et al., 2008; Kumar et al., 2009; Sekhar et al., 2010; Enanget al., 2015; Syarifahet al.,2016; Savita and singh,2017; V Ramanaet al., 2018 and Pramod et al.,2019).

Relative mid-parent heterosis for average fruit weight ranged from 5.03 percent $\left(\mathrm{P}_{3} \times \mathrm{XP}_{4}\right)$ to 25.55 percent $\left(\mathrm{P}_{2} \mathrm{xP}_{3}\right)$ and better parent heterosis from $-4.32 \%\left(\mathrm{P}_{1} \times \mathrm{P}_{4}\right)$ to $15.92 \%\left(\mathrm{P}_{1} \times \mathrm{P}_{3}\right)$.Highly significant positive heterosis was observed for average fruit weight in hybrids $\mathrm{P}_{2} \times \mathrm{P}_{3}(25.55 \%)$ followed by $\mathrm{P}_{2} \times \mathrm{P}_{4}(24.56 \%), \mathrm{P}_{1} \mathrm{PP}_{3}(16.36 \%), \mathrm{P}_{2} \times \mathrm{P}_{5}(11.00 \%)$ and $\mathrm{P}_{1} \mathrm{XP}_{2}(10.03 \%)$ over mid parent. Significant positive heterosis was observed for two hybrids $\mathrm{P} 3 \mathrm{xP} 4(5.03 \%)$ and $\mathrm{P}_{1} \times \mathrm{P}_{4}(2.26 \%)$ over mid parent. But only one hybrid $\left(\mathrm{P}_{1} \mathrm{XP}_{3}\right)$ with $15.92 \%$ increase played highly significant positive heterosis over high parent. Average fruit weight directly affects the total fruit yield, so this character is very important so far fruit yield is concerned. (Singh et al., 2005; Asati et al., 2007; and Singh and Asati, 2011) also reported positive heterosis for average fruit weight in tomato. Similar results were also obtained by (Dod et al.,1995; Kurian et al. ,2001; Kumar et al., 2009; Singh et al., 2006; Kumari and Sharma, 2011; Shankar et al., 2013; Solieman et al.,2013; Madhavi et al., 2013; Syarifah et al.,2016; Vramana et al.,2018; and Pramod et al.,2019).

Heterosis for number of Fruits / plant was found in a range of $-25.63 \%\left(\mathrm{P}_{4} \times \mathrm{P}_{5}\right)$ to $13.97 \%\left(\mathrm{P}_{1} \mathrm{x}\right.$ $\left.\mathrm{P}_{5}\right)$ for mid parent and $-13.76 \%\left(\mathrm{P}_{2} \times \mathrm{P}_{5}\right)$ to $-40.21 \%\left(\mathrm{P}_{4} \times \mathrm{P}_{5}\right)$ over better parent .

The highly significant positive heterosis was found for $\mathrm{P}_{1} \times \mathrm{P}_{5}(13.97 \%)$ followed by $\mathrm{P}_{1} \times \mathrm{P}_{3}$ (8.51\%).Significant useful positive heterosis was observed for the two hybrids $\mathrm{P}_{2} \mathrm{xP}_{4}(8.98)$ and $\mathrm{P}_{1} \mathrm{xP}_{2}$ $(2.90 \%)$ over midparent. None of the hybrids was found with significant or highly significant useful effects over high parent.

Number of fruits directly affects the total fruit yield per plant, so this character is very important for fruit yield. These findings are in close agreement with (Dundi and Madalagaeri,1991;Kumar et al.,2006;Asati et al.,2007;Saleemet al.,2009;Kumari and Sharma ,2011; Shankar et al.,2013;Solieman et al.,2013;Madhaviet al.,2013;Syarifah et al.,2016;Savita and singh,2017; VRamana et al., 2018; and Pramod et al.,2019).

Midparent heterosis of total fruit yield ranged from -4.65 percent $\left(\mathrm{P}_{4} \mathrm{xP}_{5}\right)$ to 11.55 percent $\left(\mathrm{P}_{1} \mathrm{xP}_{5}\right)$ and better parent heterosis from -3.55 percent $\left(\mathrm{P}_{1} \mathrm{XP}_{4}\right)$ to 7.08 percent $\left(\mathrm{P}_{1} \times \mathrm{P}_{5}\right)$. Total fruit yield per plant is the most important trait which deserve highest consideration in any breeding program. Highly significant positive heterosis was observed for the two hybrids $\mathrm{P}_{1} \times \mathrm{P}_{5}(11.55 \%)$ and $\mathrm{P}_{3} \times \mathrm{P}_{5}(10.47 \%)$ over mid parent, and the two hybrids $\mathrm{P}_{1} \times \mathrm{P}_{5}(7.08 \%)$ and $\mathrm{P}_{3} \times \mathrm{P}_{5}(4.64 \%)$ over high parent, but only one hybrid $\left(\mathrm{P}_{2} \times \mathrm{P}_{3}\right) \quad 2.95 \%$ played significant positive heterosis over mid parent. Crosses $\mathrm{P}_{1} \times \mathrm{P}_{5}$ and $\mathrm{P}_{3} \times \mathrm{P}_{5}$ were the best crosses for fruit yield per plant the high heterosis for that trait may be due to dominance nature of gene.

These results are in accordance with (Shankar et al., 2013; Madhavi et al.,2013) and the increased yield in these hybrids may be due to the high yielding parents used in hybridization as suggested by Courtney and Peirce(1979)

\section{Analysis of variance for different characters studied}

Analysis of variance (Table 4) indicated highly significant variances among genotypes for all the studies traits.

\section{Combiningability}

The combining ability plays a pivotal role together with per se performance of parents, hybrids and heterotic response in selecting potential parents and hybrids. 


\section{Analysis of variance of combining ability}

Analysis of variance (Table 4) indicated highly significant variances among genotypes for all characters under study. The analysis of variance for combining ability partitioned genetic variation into GCA and SCA components. Mean squares from the analysis of GCA and SCA were highly significant for all traits under study, except number of branches per plant and fruit shape; indicating genetic diversity among the parent (GCA), thus highest contribution by these characters towards combining ability, and suggesting the importance of both additive $\left(a^{2} A\right)$ and non- additive $\left(a^{2} D\right)$ gene actions in the inheritance of all the studies traits.

For Plant height, number of branches per plant, number of leaves per plant, leaf area index, fruit length, fruit diameter, T.S.S., fruit locules, average fruit weight, number of fruit per plant and total fruit weight, (Table 4) the variance due to GCA was higher than these of SCA and the ratio of GCA/SCA were found more than one(ranged from 7.43 to 26.97), indicating the major control of additive gene action and also supported by $\left(a^{2} \mathrm{~A} / \mathrm{a}^{2} \mathrm{D}\right)$ ratio (Table 7) which was found more than one, since average degree of dominance value ranged from ( 0.17 to 3.71 ).

For number of branches and fruit shape, the variance due to highly significant specific combing ability (SCA) was higher than these of non-significant general combing ability (GCA), indicating the major control of non- additive type of gene action in tomato. The non-additive variance was further confirmed by the ratio of $\left(a^{2} \mathrm{~A} / \mathrm{a}^{2} \mathrm{D}\right)$ which found less than one $(0.01$ and 0.57$)$ for number of branches and fruit shape, respectively. Also, the degree of dominance was more than one (3.71 and 1.41) for number of branches and fruit shape, respectively, indicating over-dominance and epistatic interaction for these traits.

On the other hand, significant and negative GCA were found in $\left(\mathrm{P}_{1}, \mathrm{P}_{2}, \mathrm{P}_{3}\right.$ and $\left.\mathrm{P}_{4}\right)$ for plant height, $\left(\mathrm{P}_{3}\right.$ and $\left.\mathrm{P}_{4}\right)$ for No. of branches/plant and leaf area index, $\left(\mathrm{P}_{2}\right.$ and $\left.\mathrm{P}_{3}\right)$ for No. of leaves/plant, $\left(\mathrm{P}_{1}, \mathrm{P}_{2}\right.$ and $\left.\mathrm{P}_{3}\right)$ for fruit length, fruit diameter, T.S.S. and number of fruit locules, $\left(\mathrm{P}_{1}\right.$ and $\left.\mathrm{P}_{2}\right)$ for total fruit yield and $\left(\mathrm{P}_{2}\right.$ and $\left.\mathrm{P}_{5}\right)$ for Average fruit weight.

\section{Effect of General combing ability (GCA):}

The estimates of GCA of the parents for different traits are given in (Table 5). The good combiner parents for the studied traits were $\mathrm{P}_{5}$ for Plant height, No. of branches, no. of leaves, fruit length, fruit diameter, fruit shape, fruit locules, No. of fruit per plant and total fruit weight per plant. $(2.97,11.04,0.08,1.04,0.04,0.32,1.27$ and 0.05$) \mathrm{P}_{2}$ for leaf area index, fruit shape and No. of fruit per plant (15.62, 0.14 and 8.31), $\mathrm{P}_{4}$ for No. of leaves, fruit length, fruit diameter, fruit locules and Average fruit weight $(11.80,0.46,1.39,0.90$ and 10.00$), \mathrm{P}_{3}$ for fruit shape, T.S.S., average fruit weight and total fruit yield and P1 for leaf area index and average fruit weight.

\section{Effect of specific combing ability (SCA):}

The cross combination showed (Table 6) highest positive significant specific combining ability effect $\left(\mathrm{P}_{1} \times \mathrm{P}_{2}\right)$ for plant height, $\left(\mathrm{P}_{1} \times \mathrm{P}_{3}\right)$ for No. of branches/ plant, $\left\{\left(\mathrm{P}_{2} \times \mathrm{P}_{5}\right),\left(\mathrm{P}_{1} \times \mathrm{P}_{4}\right),\left(\mathrm{P}_{3} \times\right.\right.$ $\left.\mathrm{P}_{5}\right)$ and $\left.\left(\mathrm{P}_{3} \times \mathrm{P}_{4}\right)\right\}$ for No. of leaves / plant. All the cross combination over mid- parent heterosis, $\left\{\left(\mathrm{P}_{2}\right.\right.$ x $\left.\mathrm{P}_{3}\right)$ and $\left.\left(\mathrm{P}_{3} \times \mathrm{P}_{5}\right)\right\}$ for leaf area index., $\left\{\left(\mathrm{P}_{2} \times \mathrm{P}_{5}\right),\left(\mathrm{P}_{1} \times \mathrm{P}_{4}\right),\left(\mathrm{P}_{1} \times \mathrm{P}_{5}\right),\left(\mathrm{P}_{2} \times \mathrm{P}_{4}\right)\right.$ and $\left.\left(\mathrm{P}_{2} \times \mathrm{P}_{3}\right)\right\}$ for fruit length, $\left\{\left(\mathrm{P}_{3} \times \mathrm{P}_{4}\right),\left(\mathrm{P}_{3} \times \mathrm{P}_{5}\right),\left(\mathrm{P}_{1} \times \mathrm{P}_{4}\right),\left(\mathrm{P}_{2} \times \mathrm{P}_{5}\right)\right.$ and $\left.\left(\mathrm{P}_{1} \times \mathrm{P}_{5}\right)\right\}$ for fruit diameter, $\left\{\left(\left(\mathrm{P}_{2} \times \mathrm{P}_{3}\right),(\right.\right.$ $\left.\mathrm{P}_{4} \times \mathrm{P}_{5}\right)$ and $\left.\left(\mathrm{P}_{2} \times \mathrm{P}_{4}\right)\right\}$ for fruit shape, $\left\{\left(\mathrm{P}_{4} \times \mathrm{P}_{5}\right)\right.$ and $\left.\left(\mathrm{P}_{1} \times \mathrm{P}_{4}\right)\right\}$ for T.S.S., $\left\{\left(\mathrm{P}_{3} \times \mathrm{P}_{5}\right),\left(\mathrm{P}_{2} \times \mathrm{P}_{4}\right),(\right.$ $\left.\mathrm{P}_{1} \times \mathrm{P}_{2}\right),\left(\mathrm{P}_{2} \times \mathrm{P}_{5}\right)$ and $\left.\left(\mathrm{P}_{1} \times \mathrm{P}_{4}\right)\right\}$ for number of fruit locules. Among the cross combinations, 3 crosses over mid-parent, $\left\{\left(\mathrm{P}_{2} \times \mathrm{P}_{4}\right),\left(\mathrm{P}_{1} \times \mathrm{P}_{3}\right)\right.$ and $\left.\left(\mathrm{P}_{2} \times \mathrm{P}_{3}\right)\right\}$ for fruit weight. Average fruit weight directly affects the total fruit yield, so this character is very important so far fruit yield is concerned., $\left\{\left(\mathrm{P}_{1} \times \mathrm{P}_{5}\right)\right.$ and $\left.\left(\mathrm{P}_{2} \times \mathrm{P}_{4}\right)\right\}$ for no. of fruit / plant. and $\left\{\left(\mathrm{P} 1 \times \mathrm{P}_{5}\right)\right.$ and $\left.\left(\mathrm{P}_{3} \times \mathrm{P}_{5}\right)\right\}$ for Total fruit yield Crosses showing high SCA for fruit yield involved parents showing high GCA for numbers of fruit per flower cluster or numbers of fruit per plant or fruit weight or fruit diameter (Shende et al., 2012; Chandarshive et al., 2015; Triveni et al., 2017;Nidhish et al., 2018;Gayosso et al., 2019; and Nisha et al., 2019). The cross showing significant SCA value, provided that at least one of its parents had high desirable GCA effect, is expected to produce favorable transgrassivesegregants through hybridization with delayed selection (because of dominance and epistatic interactions) if the complementary epistatic effect present in that cross acts in the same direction to maximize desirable plant attributes (Salimath \& Bahi, 1985). 
Table 4: Half Diallel analysis of varieties and the mean square of F1 hybrids and their parents for All traits in 2018 season

\begin{tabular}{|c|c|c|c|c|c|c|c|c|c|c|c|c|c|}
\hline \multirow[b]{2}{*}{ S.O.V. } & \multirow[b]{2}{*}{ d.f. } & \multicolumn{12}{|c|}{ M.S. } \\
\hline & & $\begin{array}{c}\text { Plant } \\
\text { Height } \\
\text { (cm) }\end{array}$ & $\begin{array}{c}\text { No. of } \\
\text { Branches } \\
\text { /plant }\end{array}$ & $\begin{array}{c}\begin{array}{c}\text { No. } \\
\text { of } \\
\text { Leaves } \\
\text { /plant }\end{array} \\
\end{array}$ & $\begin{array}{l}\text { Leaf } \\
\text { area } \\
\text { index }\end{array}$ & $\begin{array}{c}\text { Fruit } \\
\text { Length }\end{array}$ & $\begin{array}{c}\text { Fruit } \\
\text { diameter }\end{array}$ & $\begin{array}{l}\text { Fruit } \\
\text { shape } \\
\text { index }\end{array}$ & T.S.S. & $\begin{array}{c}\text { No. } \\
\text { of } \\
\text { Fruit } \\
\text { locules }\end{array}$ & $\begin{array}{c}\text { Aver. } \\
\text { Fruit } \\
\text { weight }\end{array}$ & $\begin{array}{c}\text { No. } \\
\text { of } \\
\text { fruits/ } \\
\text { plant }\end{array}$ & $\begin{array}{c}\text { Total } \\
\text { fruit } \\
\text { weight } \\
\text { (kg) }\end{array}$ \\
\hline Genotype & 14 & $633.47 * *$ & $5.85^{* *}$ & $932.04 * *$ & $970.72 * *$ & $2.835^{* *}$ & $8.75 * *$ & $0.0972 * *$ & $5.44 * *$ & $3.032 * *$ & $648.17 * *$ & $186.65 * *$ & $0.094 * *$ \\
\hline GCA & 4 & $1771.23 * *$ & 5.98 & $2952.50 * *$ & $2619.39 * *$ & $7.643 * *$ & $27.05^{* *}$ & 0.1892 & $14.31 * *$ & $7.939 * *$ & $1892.30 * *$ & $597.86^{* *}$ & $0.249 * *$ \\
\hline SCA & 10 & $178.37 * *$ & $5.79 * *$ & $123.85^{* *}$ & $311.25^{* *}$ & $0.912 * *$ & $1.44 * *$ & $0.0604 * *$ & $1.90 * *$ & $1.069 * *$ & $150.52 * *$ & $22.17 * *$ & $0.032 * *$ \\
\hline Error & 28 & 3.97 & 1.26 & 5.29 & 11.54 & 0.009 & $0.02 * *$ & 0.0011 & 0.01 & 0.004 & 6.47 & 3.27 & 0.002 \\
\hline
\end{tabular}

Table 5: Estimation of general combined ability (gi) of each parents line for all traits in 2018 season

\begin{tabular}{|c|c|c|c|c|c|c|c|c|c|c|c|c|}
\hline Crosses & $\begin{array}{l}\text { Plant } \\
\text { Height } \\
\text { (cm) }\end{array}$ & $\begin{array}{c}\text { No. } \\
\text { of } \\
\text { branches } \\
\text { /plant }\end{array}$ & $\begin{array}{c}\begin{array}{c}\text { No. } \\
\text { of } \\
\text { Leaves } \\
\text { /plant }\end{array} \\
\end{array}$ & $\begin{array}{l}\text { Leaf } \\
\text { area } \\
\text { index }\end{array}$ & $\begin{array}{l}\text { Fruit } \\
\text { length }\end{array}$ & $\begin{array}{c}\text { Fruit } \\
\text { diameter }\end{array}$ & $\begin{array}{l}\text { Fruit } \\
\text { shape } \\
\text { index }\end{array}$ & T.S.S & $\begin{array}{l}\text { No. of } \\
\text { Fruit } \\
\text { locules }\end{array}$ & $\begin{array}{c}\text { Aver. } \\
\text { fruit } \\
\text { weight (g) }\end{array}$ & $\begin{array}{l}\text { No. of } \\
\text { fruits/ } \\
\text { plant }\end{array}$ & $\begin{array}{c}\text { Total } \\
\text { fruit } \\
\text { weight } \\
\text { (kg) }\end{array}$ \\
\hline 1 & $-14.81 * *$ & 0.3 & 0.75 & $3.46^{* *}$ & $-0.61 * *$ & $-0.64 * *$ & $-0.03 * *$ & $-0.149 * *$ & $-0.16^{* *}$ & $3.14 * *$ & $-3.02 * *$ & $-0.06^{* *}$ \\
\hline 3 & $-4.96 * *$ & $-0.47 *$ & $-15.15^{* *}$ & $-14.56^{* *}$ & $-0.41 * *$ & $-0.62 * *$ & $0.05 * *$ & $1.344 * *$ & $-0.61 * *$ & $4.90 * *$ & $-0.78 * *$ & $0.17 * *$ \\
\hline 4 & $-7.47 * *$ & $-0.66^{* *}$ & $11.8^{* *}$ & $-5.48 * *$ & $0.46^{* *}$ & $1.39 * *$ & $-0.11 * *$ & $-0.902 * *$ & $-0.90 * *$ & $10.00 * *$ & $-5.78 * *$ & $-0.10^{* *}$ \\
\hline 5 & $2.97 * *$ & $0.58 *$ & $11.04 * *$ & 0.96 & $0.80 * *$ & $1.04 * *$ & $-0.04 * *$ & -0.005 & $0.32 * *$ & $-3.38 * *$ & $1.27 * *$ & $0.05^{* *}$ \\
\hline SD (Gi) & 0.39 & 0.22 & 0.45 & 0.66 & 0.02 & 0.03 & 0.006 & 0.022 & 0.012 & 0.50 & 0.35 & 0.009 \\
\hline
\end{tabular}


Table 6: Estimation of Specific combing ability effects for each cross for all traits in 2018 season

\begin{tabular}{|c|c|c|c|c|c|c|c|c|c|c|c|c|}
\hline Crosses & $\begin{array}{c}\text { Plant } \\
\text { Height } \\
\text { (cm) }\end{array}$ & $\begin{array}{l}\text { No. of } \\
\text { Branches } \\
\text { /plant }\end{array}$ & $\begin{array}{l}\text { No. of } \\
\text { Leaves } \\
\text { /plant }\end{array}$ & $\begin{array}{l}\text { Leaf } \\
\text { area } \\
\text { index }\end{array}$ & $\begin{array}{l}\text { Fruit } \\
\text { length }\end{array}$ & $\begin{array}{c}\text { Fruit } \\
\text { diameter }\end{array}$ & $\begin{array}{l}\text { Fruit } \\
\text { shape } \\
\text { index }\end{array}$ & T.S.S & $\begin{array}{c}\text { Fruit } \\
\text { locules } \\
\text { number }\end{array}$ & $\begin{array}{c}\text { Aver. } \\
\text { Fruit } \\
\text { Weight } \\
\text { (g) }\end{array}$ & $\begin{array}{c}\text { No. of } \\
\text { fruits/ } \\
\text { plant }\end{array}$ & $\begin{array}{c}\text { Total } \\
\text { fruit } \\
\text { Weight } \\
\text { (kg) }\end{array}$ \\
\hline $\mathbf{P}_{1} \times \mathbf{P}_{2}$ & $15.71 * *$ & -0.25 & 0.29 & -1.35 & $-0.85^{* *}$ & $-0.22 * *$ & $-0.135^{*}$ & 0.05 & $0.32 * *$ & -0.36 & -0.20 & -0.009 \\
\hline$P_{1} \times P_{3}$ & $-8.13^{* *}$ & $2.79 *$ & $-4.34 * *$ & -1.07 & -0.04 & $-0.27 * *$ & 0.002 & $-0.22 * *$ & $-0.38 * *$ & $9.39 * *$ & 0.89 & $0.088 * *$ \\
\hline$P_{1} \times P_{4}$ & $-2.29 *$ & 0.32 & $8.71 * *$ & 2.01 & $0.59 * *$ & $0.77 * *$ & -0.007 & $0.21 * *$ & $0.09 * *$ & -2.03 & -2.11 & -0.038 \\
\hline$P_{1} \times P_{5}$ & $9.82 * *$ & 0.41 & 1.81 & $-8.77 * *$ & $0.19 * *$ & $0.31 * *$ & 0.002 & 0.07 & $-0.28 * *$ & 0.68 & $3.84 * *$ & $0.184 * *$ \\
\hline $\mathbf{P}_{2} \times \mathbf{P}_{3}$ & 0.61 & -1.16 & $-5.81 * *$ & $22.01 * *$ & $0.14^{* *}$ & $-0.68 * *$ & $0.208^{* *}$ & $-0.71 * *$ & $-0.53 * *$ & $8.87 * *$ & -0.11 & $0.048 *$ \\
\hline $\mathbf{P}_{2} \times \mathbf{P}_{4}$ & $-5.06^{* *}$ & 1.03 & 0.90 & $-7.83 * *$ & $0.18 * *$ & $-0.47 * *$ & $0.039 *$ & 0.04 & $0.57 * *$ & $10.47 * *$ & $3.22 * *$ & -0.022 \\
\hline $\mathbf{P}_{3} \times \mathbf{P}_{4}$ & 0.23 & -0.59 & $4.62 * *$ & $-12.08 * *$ & $-0.67 * *$ & $0.84 * *$ & $-0.224 * *$ & $-1.60 * *$ & $-0.46^{* *}$ & -0.79 & 1.31 & 0.019 \\
\hline $\mathbf{P}_{3} \times \mathbf{P}_{5}$ & $-2.26^{*}$ & $-2.16^{* *}$ & $7.05 * *$ & $6.34 * *$ & $-0.71 * *$ & $0.78 * *$ & $-0.215 * *$ & $-0.49 * *$ & $1.33 * *$ & $-4.08 * *$ & 0.60 & $0.161 * *$ \\
\hline $\mathbf{P}_{4} \times \mathbf{P}_{5}$ & $-3.65^{* *}$ & 0.03 & $-7.57 * *$ & -1.24 & 0.07 & $-1.05 * *$ & $0.136^{* *}$ & $0.23 * *$ & $-0.57 * *$ & 1.16 & $-5.73 * *$ & $-0.099 * *$ \\
\hline SD(sij) & 1.00 & 0.57 & 1.16 & 1.71 & 0.05 & 0.07 & 0.017 & 0.06 & 0.03 & 1.28 & 0.91 & 0.023 \\
\hline SD(sij-sji) & 1.06 & 0.60 & 1.23 & 1.82 & 0.05 & 0.08 & 0.018 & 0.06 & 0.03 & 1.36 & 0.97 & 0.024 \\
\hline SD(sij-sik) & 1.51 & 0.85 & 1.74 & 2.57 & 0.07 & 0.11 & 0.025 & 0.09 & 0.05 & 1.92 & 1.37 & 0.034 \\
\hline SD(sij-skD) & 1.37 & 0.77 & 1.59 & 2.34 & 0.07 & 0.10 & 0.023 & 0.08 & 0.04 & 1.76 & 1.25 & 0.031 \\
\hline
\end{tabular}

Table 7: Estimation of genetic parameters and hertabilities in broad sense (h2b) and narrow senses (h2n) for all traits in 2018 season

\begin{tabular}{|c|c|c|c|c|c|c|c|c|c|c|c|c|}
\hline Crosses & $\begin{array}{c}\text { Plant } \\
\text { height }(\mathrm{cm})\end{array}$ & $\begin{array}{c}\text { No. of } \\
\text { branches } \\
\text { /plant }\end{array}$ & $\begin{array}{c}\text { No. of } \\
\text { Leaves } \\
\text { /plant }\end{array}$ & $\begin{array}{l}\text { Leaf } \\
\text { area } \\
\text { index }\end{array}$ & $\begin{array}{l}\text { Fruit } \\
\text { length }\end{array}$ & $\begin{array}{c}\text { Fruit } \\
\text { diameter }\end{array}$ & $\begin{array}{l}\text { Fruit } \\
\text { shape } \\
\text { Index } \\
\end{array}$ & T.S.S & $\begin{array}{c}\text { No. of } \\
\text { Fruit } \\
\text { locules }\end{array}$ & $\begin{array}{c}\text { Aver. Fruit } \\
\text { weight(g) }\end{array}$ & $\begin{array}{c}\text { No. of } \\
\text { fruits/plant }\end{array}$ & $\begin{array}{l}\text { Total fruit } \\
\text { weight (kg) }\end{array}$ \\
\hline$a^{2} A$ & 151.7 & 0.016 & 269.38 & 219.82 & 0.640 & 2.440 & 0.0122 & 1.182 & 0.654 & 165.88 & 54.82 & 0.0208 \\
\hline$a^{2} D$ & 58.13 & 1.51 & 39.52 & 99.90 & 0.301 & 0.473 & 0.0198 & 0.628 & 0.355 & 48.02 & 6.30 & 0.0101 \\
\hline$a^{2} E$ & 1.32 & 0.42 & 1.76 & 3.84 & 0.003 & 0.007 & 0.0004 & 0.004 & 0.001 & 2.16 & 1.09 & 0.0007 \\
\hline$h^{2} b \%$ & 99.37 & 78.42 & 99.43 & 98.81 & 99.682 & 99.760 & 98.765 & 99.780 & 99.900 & 99.00 & 98.25 & 97.78 \\
\hline$h^{2} n \%$ & 71.84 & 0.82 & 86.71 & 67.94 & 67.797 & 83.562 & 37.654 & 65.160 & 64.752 & 76.77 & 88.12 & 64.82 \\
\hline $\begin{array}{l}\text { Degree of } \\
\text { Dominance }\end{array}$ & 0.45 & 3.71 & 0.19 & 0.52 & 0.55 & 0.24 & 1.41 & 0.59 & 0.60 & 0.35 & 0.17 & 0.58 \\
\hline
\end{tabular}




\section{Estimation of Heritability}

Robinson et al. (1952) defined heritability in both broad and narrow senses. In the broad sense, it is the ratio of the total variance to the total phenotypic variance and in narrow sense it is the ratio of additive genetic variance to the total phenotypic variance. He also categorized the heritability estimates as low $(5$ to $10 \%)$ medium (10-30\%) and higher $(>30 \%)$.

Heritability estimates in broad sense (Table 7) was high, for all characters: plant height (99.37\%),number of branches per plant (78.42\%), number of leaves per plant (99.43\%), leaf area index (98.81\%), fruit length ( $99.682 \%)$, fruit diameter ( 99.760), fruit shape ( $98.765 \%)$, T.S.S. $(99.780 \%)$, number of locules per fruit $(99.90 \%)$, average fruit weight $(99.00 \%)$, number of fruits per plant ( $98.25 \%$ )and total fruit yield ( $97.78 \%$ ) heritability. High heritability indicates the scope of genetic improvement of these traits through selection. Similar result has been recorded by (Joshi et al., 2004; Shashikanth et al., 2010; Rahaei et al., 2017; Nidhish et al., 2018 and Saravanan et al., 2019).

Heritability estimates in narrow sense is shown in (Table 7). The high narrow sense heritability were for plant height $(71.84 \%)$, number of leaves per plant ( $86.71 \%)$, leaf area index $(67.94 \%)$, fruit length ( 67.797\%), fruit diameter ( 83.562 ), fruit shape ( $37.654 \%)$, TSS $(65.160 \%)$, number of locules per fruit $(64.752 \%)$, average fruit weight $(76.77 \%)$, number of fruits per plant $(88.12 \%)$ and total fruit yield ( $64.82 \%$ ). But, estimates low narrow sense heritability were for number of branches per plant $(0.82 \%)$ heritability. Similar results have been reported by (Kumariet al., 2007; Islam et al., 2012; Manna and Paul, 2012; Mohamed et al., 2012; Rahaei et al., 2017; Nidhish et al., 2018; and Saravanan et al., 2019).

\section{Conclusion}

From the present investigation, it can be concluded that the tomato parents 'Super Marmande', Super strain B and Red Starare best general combiner and could be utilized in multiple crossing program to develop tomato yield components. The two crosses Super Marmande’x Red Star' and Super strain B ' ' Red Star' had at least one good general combiner parents and with high SCA effect, thus suggesting heterosis breeding as a-valid strategy for the development of vigorous high yielding hybrid varieties and quality components.

\section{References}

Andre, K., 1972. The great increase in relative volatibility on Real Wag in the United States 210 Meeting Papers 674Society for Economic Dynamics.

Asati, B.S., G. Singh, N. Rai, and A.K. Chaturvedi, 2007. Hetrosis and combining ability studies for yield and quality traits in tomato. Veg. Sci., 34(1): 92-94.

Bhatt, GM., 1971. Heterotic Performance and Specific combining ability in relation to Diallel crossing system. Australian J. Biol. Sci., 9:463-393

Berry, S.Z. and M.R. Uddin, 1991. Breeding tomato for quality and processing attributes. In: Kalloo, G. ed. Genetic Improvement of Tomato. Berlin, Springer-Verlag Press. pp. 196-206.

Chandarshive, A.V., M. K.Rana, S.Y. Dharka, and Y. Neha, 2015. Studies on combining ability analysis for yield and yield related traits in tomato (Solanum lycopersicum L.). Enz. Eng., 4(2):2339-2344

Courtney, W.H. and I.C. Peirce,1979. Parent selection in tomato based on morpho-physiological traita. Hort.Sci.,14:458.

Cochran, W.C. and G.M. Cox, 1957. Experimental design $2^{\text {nd }}$ ed., Jan willey and Sons. New York.SA.

Dod, V.N., P.B. Kale, and R.V. Wankhede, 1995. Heterosis and combining ability in tomato. PKV Res. J., 19: 125-129.

Dundi, K.B., and B.B. Madalageri, 1991. Heterosis for shelf life and its components in tomato (Lycopersicion esculentum Mill.) South Indian Horticulture, 39(6):353-355.

Enang, E. M., A. M. Kadams, S.Y. Simon, and S.J. Louis, 2015. Heterosis and general combing ability study on heat tolerant tomato (Lycopersicion esculentum Mill.) International Journal of horticulture, 5(17):2325-2337.

Frusciante, L., A. Barone, D. Carputo, M.R. Ercolano, F. Rocca, and S. Esposito, 2000. Evaluation and use of plant biodiversity for food and pharmaceuticals. Fitoterapia, 71: 566-572.

Geleta, L.F. and M.T. Labuschagne, 2004. Comparative performance and heterosis in single, threeway and double cross pepper hybrids. J. Agric. Sci., 142: 659-663. 
Gayasso, O. B., B. Lopez, H. Rodriguez, J. N.Mass, R. Hidalgo, and Alcola , 2019. Studies on combing ability in tomato (Solanum lycopersicum L.). Agronomy Research 17(1) 77-85.

Griffing, B., 1956. Concept of general and specific combining ability in relation to diallel crossing system. Australian J. Biological Sci., 9: 463-93.

Hallauer, A.R.,1999. Heterosis. What have we learned? What have we done? Where are we headed? In: J.G Coors and Shivaji Pandey [eds.], The Proceedings of an International Symposium "The Genetics and Exploitation of Heterosis in Crops", CIMMYT, Mexico City, Mexico, 17-22 August, 1997, Madison, USA, American Society of Agronomy, pp. 483-492.

Hassan, A.A., K.E. Abdel-Ati, S.E.S. Moustafa and A.A. Mohammed, 2000. Genetics of some tomato fruits quality characters. II. Chemical characters. Egypt. J. Hort. 27(2): 265 -274.

Hedrick, U.P. and N. Booth, 1907. Mendelian characters in tomato. J. Amer. Soc.Hort. Sci., 5: 19-23.

Islam, M.S., H.C. Mohanta, M.R. Ismail, M.Y. Rafii, and M.A. Malek, 2012. Genetic variability and trait relationship in cherry tomato (Solanum lycopersicum L.var. cerasiforme (Dunnal) A. Gray). Bangladesh J. Bot., 41(2): 163-167.

Joshi A., A. Vikram and K.S. Thakur, 2004 Genetics of yield and horticultural traits in tomato. Veg. Sci 31:112-117.

Khalf-Allah, A. M., E. M. S. Helmy and Z. Abdel-Aal, 2005. Estimates of combining abilities, heterosis and heritability of some important characters of tomato ( Lycopersicon esculentum Mill). Alex. J. Agric. Res., 50(2):137-143.

Kurian, A. and K.V. Peter, 2001. Heterosis for quality traits in tomato. J. Trop.Agric., 39: 13-16.

Kurian, A., K.V. Peter, and S. Rajan, 2001. Heterosis for yield components and fruit characters in tomato. J. Trop. Agric., 39: 5-8.

Kumar, R., N.K. Mishra, J. Singh, G.K. Rai, A. Verma, and M. Rai, 2006. Studies on yield and quality traits in tomato (Solanum lycopersicum L.). Veg. Sci., 33(2): 126-132.

Kumar, K.H.Y., S.S. Patil, P.R. Dharmatti, A.S. Byadagi, S.T. Kajjidoni, and R.H. Patil, 2009. Estimation of heterosis for tospovirus resistance in tomato. Karnataka J. Agric. Sci., 22(5): 1073-1075.

Kumari, N., J.P. Srivastava, A.K.S. Shekhavat, J.R. Yadav, and B. Singh, 2007. Genetic variability and heritability of various traits in tomato (Lycopersicon esculentum Mill.). Progr. Agric., 7(12): $80-83$.

Kumari, S. and M.K. Sharma, 2011. Exploitation of heterosis for yield and its contributing traits in tomato, (Solanum lycopersicum L.) Int. J. Farm Sci., 1(2): 45-55. 40-

Kurian, A. and K.V. Peter, 2001). Heterosis for quality traits in tomato. J. Trop. Agric., 39: 13-16.

Madhavi, Y., R.V.S.K. Reddy, M. Thirupathireddy, K. S.Sudheer and M.H.V. Bhave, 2013. Exploitation of heterosis and combining ability for yield, quality and processing, Dr. Y.S.R. Horticultural University, Andhra Pradesh.

Mahendrakar, P., 2004. Development of F1 hybrids in tomato (Lycopersicum esculentum Mill.). M.Sc. (Agri.) Thesis, Univ. Agric. Sci.

Manna, M. and A. Paul, 2012. Studies on genetic variability and characters association of fruit quality parameters in tomato. Hort Flora Res. Spectrum. 1(2): 110-116.

Mather, K. and J. 1. Jinks, 1971. Biometrical genetics components of means additive and dominance effects. (Chompmal and Hail) t.d. London P65-82

Metwally, E. L., G. El-Fadaly, and A.Y. Mazrouh, ,1996. Inheritance of yield and yield components in the tomato (Lycopersicum esculentum Mill.). Assiut J, Agric. Sci., 19: 227-238

Mohamed, S.M., E.E. Ali, and T.Y. Mohamed, 2012. Study of heritability and genetic variability among different plant and fruit characters of tomato (Solanum lycopersicon L.). Intl. J. Scientific Technol. Res., 1(2): 55-58.

Nidhish, G., K. Manish, K. Dharminder, K. Sandeep, V. Amit, K. D. Rajesh, and S. Shikha, 2018. Combining ability and gene action studies for important quality traits in tomato (Solanumlycopersicum L.) International journal of chemical studies 6(2): 1992-1996.

Nisha, T., C. Sanjay, and B.D. Mayanglambam, 2019. Drgonic Tomato: combining ability for yield and component traits in tomato (Solanum lycopersicum L.).Under Mid Himalayan Region. $8(1): 2099-2112$

Patil, G.S., 1997. Genetic analysis and economic usage of compound inflorescence in tomato Ph.D. Thesis, University of Agriculture Sciences. 
Peralta, I.E., S. Knapp, and D.M. Spooner, 2006. The taxonomy of tomatoes: A revision of wild tomatoes (Solanum L. section Lycopersicon (Mill.) Wettst.) and their out group relatives (Solanum sections Juglandifolium (Rydb.) Child and Lycopersicoides (Child) Peralta). Monogr. Syst. Bot. Garden.

Peet, M.M., D.H. Willits, and R.Gradner, 1997. Effect of night temperature on pollon characteristics growth and fruit set in tomato. J. Amer. Soci. Hort. Sci., 121(3):414-419.

Paratta, G., R. Zorzoli, and L.A. Picardi, 2003. Diallel analysis of production traits among domestic, exotic and mutant germplasm of Lycopersicon. Gen. Mol. Res., 2(2): 206-213.

Pramod, K., B. Lila, and K.M.Suneel, 2019. Heterosis studies for yield and quality traits in tomato (Lycopersicumnesculentum Mill.). J. pharmacognosy and phylochemistry 8(1): $1370-1375$.

Rahaei, J., I. Hamidoghl, and B. Rabiei, 2017.Evaluation of Gene effects and Hertability of quantitative traits in tomato through Generation mean analysis.IranianJoirnal of Horticultural Science and Technology 7(4):423-438.

Rani, C.I. and D. Veeraragavathatham, 2008. Studies on heterosis in root knot nematode (Meloidogyne incognita) resistant hybrids in tomato (Lycopersicon esculentum Mill.). The Asian J. Hort., 3(1): 40-44

Riggs, T.J., 1988. Breeding F1 hybrid varieties of vegetables. J. Hort. Sci., 63: 369-382.

Robinson, H.F., R.E. Comstock, and P.H. Harvey, ,1952. Genotypic and phenotypic correlation in corm and their implication on in selection. Agron. J., 43: 282- 287.

Salimath, P.M. and P.N. Bahl, 1985. Heterosis and combining ability for earliness in chickpea (Cicer arietinum L.). Indian J. Genet., 45: 97-100.

Saleem, M.Y., M. Asghar, M.A. Haq, T. Rafique, A. Kamran, and A.A. Khan, 2009. Genetic analysis to identify suitable parents for hybrid seed production in tomato (Lycopersicon esculentum Mill.). Pak. J. Bot., 41(3): 1107-1116.

Saravanan, K. R., V. Vishaupriya, M. Prakash, and R. Anandan, 2019.Variability heritability and genetic advance in tomato genotypes. Indian J. Agric. Rec. 53(1): 92-95

SavitaTamata and J.P. Sngh, 2017.Heterosis in tomato for Growth and Yield Traits. International jornal of Vegetable Science, DOI: 10 1080/ 19315260. 2017.1407857.

Sekhar, L., B.G. Prakash, P.M. Salimath, H.P. Channayya, O. Sridevi, and A.A. Patil, 2010. Implications of heterosis and combining ability among productive Single cross hybrids in tomato. Electr. J. Plant Breed., 1(4): 706-711.

Sharma, D. and M.C. Thakur, 2008. Evaluation of diallel progenies for yield and its contributing traits in tomato under mid hill conditions. Indian J. Hort., 65(3): 297-301.

Shankarappa, K.S., Sriharsha, K.T. Rangaswamy, D.S. Aswathanarayana, H.A. Prameela, R.S. Kulkarni, V. Muniyappa, A.M. Rao, and M.N. Maruthi, 2008. Development of tomato hybrids resistant to tomato leaf curl virus disease in South India. Euphytica, 164: 531-539.

Shankar, A., R.V.S.K. Reddy, M. Sujatha, and M. Pratap, 2013. Combining ability and gene action studies for yield and yield contributing traits in tomato (Solanum lycopersicum L.) Helix, 6: 431 -435 .

Sharma, D., D.R. Choudhary and D.P. Pandey, 2001. Studies on hybrid vigour in tomato (Lycopersicon esculentum Mill.). J. Hort. Sci., 30(3\&4): 236-238.

Shashikanth Basavaaj, N., R.M. Hosamaj, and B.C. Patil, 2010. Genetic variability in tomato (SolanumlycopersicomMill) Karnataka J. Agri Sci., 23:536-537.

Shende, V.D., T. Seth, S. Mukherjee, and A. Chattopadhyay, 2012. Breeding tomato (Solanum lycopersicum L.) for higher productivity and better processing qualities. J. Breed. Genet. 44(2):302-321.

Singh, A., J.P.S. Gautam, M. Upadhyay and A. Joshi, 2005. Heterosis for yield and quality characters in tomato. Crop Res., 29(2): 285-287.

Singh, P.K., B.Singh, J.P. Singh, and S.Singh, 2006. Combining ability in tomato (Solanum lycopersicon Mill.) Wettsd.). Veg. Sci., 33(1): 85-87.

Singh, K.P., G. Mandal, and B.C. Saha, 2006. Genetic variability of yield components and biochemical characters in spring season tomato (Lycopersicon esculentum Mill.). J. InteraCademicia, 10 (3): 314-318.

Singh, A.K., R.S. Pan, and M. Rai, 2006. Heterosis for fruit yield and its components in tomato (Solanum lycopersicon (Mill.) Wettsd.). Veg. Sci., 33(2): 190-191. 
Singh, A.K., R.S. Pan, and M. Rai, 2007. Heterosis for fruit yield and its components in tomato (Solanum lycopersicon Mill.). Veg. Sci., 34(1): 108.

Singh, C.B., N. Rai, R.K. Singh, M.C. Singh, A.K. Singh, and A.K. Chaturvedi, 2008. Heterosis, combining ability and gene action studies in tomato (solanum lycopersicum 1.). Veg. Sci., 35(2): 132-135.

Singh, A.K. and B.S. Asati, 2011. Combining ability and heterosis studies in tomato under bacterial wilt condition. Bangladesh J. Agric. Res., 36(2): 313-318.

Solieman, T.H.I., M.A.H. El-Gabry, and A.I. Abido, 2013. Heterosis, potence ratio and correlation of some important characters in tomato (Solanum lycopersicum L.) Scientia Hortic., 150: 25-30.

Syarifah, I. A., S. Wahyuni, S. Mohames, and R.W. Jaka, 2016. The estimation of components in tomato (Solanum lycopersicon Mill.).At lowland. Journal of crop Breading and Genetics. 2(1): $23-29$.

Triveni, D., P.Saidaiah, K.Rarinder, and S. Pandrarada, 2017. Studies on combing ability and gene action for growth and quality characters in tomato (Solanum lycopersicum L.). Int. J. pure App. Biosci. 5(4): 1835-1840.

Vramana, D. Srihari, R.V.S.K. Reddy, M. Sujatha and M.H.V. Bhave, 2018. Estimation of heterosis in tomato (Solanum lycopersicum L.) for yield attributes and yield. Journal of pharmacognosy and phytochemistry Sp, 1:104-108.

Wellington, R., 1912. Influence of crossing in increasing the yield of tomato. Bull. N.Y. Agric. Exp. Sta, 346: 57-76. 